\title{
HAEMORRHAGIC INFARCTION OF THE KIDNEY TREATED BY NEPHRECTOMY
}

\author{
BY \\ C. DENLEY CLARK and J. D. PICKUP \\ From the Clayton Hospital, Wakefield
}

(RECEIVED FOR PUBLICATION MARCH 13, 1953)

A review of the literature indicates that successful nephrectomy for haemorrhagic infarction of the kidney has been reported in only five instances. In America Campbell and Matthews (1942) described two cases and Milburn (1952) one case, in Sweden Sandblom (1948) described one, while in this country the only case record is by Parry (1951). The occurrence of a further case is thought worthy of record.

\section{Case Report}

S.P. was a full term female infant born on January 23 , 1952, weighing $7 \mathrm{lb}$. Two days later she developed a pustule behind the ear. She was treated with chloramphenicol but the lesion progressed to form an abscess which was incised. On February 2 the baby became very fretful and developed a temperature of $100^{\circ} \mathrm{F}$.

On examination slight evidence of dehydration was noted and there was marked harlequin mottling of the skin. The kidney was enlarged and easily palpable in the left loin.

The urine contained much albumin and a few red cells on microscopic examination. The urine was sterile on culture.

Blood examination gave haemoglobin, $98 \%$ (Haldane); red blood cells, 4,600,000 per c.mm.; white blood cells, 22,000 per c.mm. (polymorphs $50 \%$, lymphocytes $47 \%$, monocytes $3 \%$ ). On February 5 the blood urea concentration was $40 \mathrm{mg} . \%$.

Diodranil was given intramuscularly, but the pyelograms were unsatisfactory.

In view of these findings, it was felt that the diagnosis lay between a perinephric abscess, congenital hydronephrosis or a renal infarct.

The operation was performed on February 5, 1952, under general anaesthesia. A left lumbar incision was used. The left kidney was enlarged and completely infarcted, presenting as a friable mass of blood clot, in which it was almost impossible to distinguish any renal tissue. The left renal vein was thrombosed, but there was no evidence of thrombosis in the vena cava. Left nephrectomy was performed. Post-operatively $100 \mathrm{ml}$. of 1 in 5 normal saline was given subcutaneously.

The post-operative course was rather stormy for the next three days. Slight sepsis in the wound responded to treatment with streptomycin. The baby, fed on expressed breast milk, was at first slow in taking the feeds, but gradually feeding at the breast was re-established. On February 6 the blood urea level was $54 \mathrm{mg} . \%$ and by February 11 it had fallen to $29 \mathrm{mg} . \%$. The urine contained only a trace of albumin and no red blood cells on February 16. By March 11 the blood urea level had risen to $80 \mathrm{mg} . \%$ and on July 10 to $90 \mathrm{mg} . \%$, but the urine was clear of albumin and blood.

The child is now active and feeding well and at 1 year of age weighs $18 \mathrm{lb}$. $15 \mathrm{oz}$. The blood urea level had fallen to $30 \mathrm{mg} . \%$ on January $22,1953$.

Pathological Report. Dr. W. L. Rose reported as follows:

'The kidney was submitted for examination in $a=$ fragmented condition. The parenchyma was firm and red, having the appearance of an infarction. Histological examination of the kidney shows gross parenchymatous haemorrhage, which is causing disruption of the renal tissue. Towards the cortex of the kidney the haemorrhage is less and the glomerular and the tubular architecture is "living" and reasonably well defined. Search throughout the sections reveals early organizing venous thrombi. I am of the opinion that this is an infarction of the kidney due to extensive venous thrombosis of the renal veins.'

\section{Discussion}

In retrospect the diagnosis of renal infarction could have been made with more certainty in view of the previous history of sepsis associated with the clinical findings, and the presence of albumin and red blood cells in the urine. It should be emphasized that the urine was never macroscopically bloodstained, nor was it infected, although both these features are regarded by Parry (1951) as being points helpful in making the diagnosis.

A rise in the blood urea level after operation is in keeping with the experience of Milburn (1952), who believes that this is due to the occurrence of lower nephron nephritis in the remaining kidney. Although there was a persistent azotaemia in our case for six months, there was no accompanying albu- 
minuria, the absence of which would be unlikely in a lower nephron nephritis.

\section{Summary}

A case of unilateral renal thrombosis occurring in the neonatal period is described.
We are grateful to Dr. W. L. Rose for his histological and biochemical reports, and to Mr. J. M. McKiddie for access to his case records.

\section{REFERENCES}

Campbell, M. F. and Matthews, W. F. (1942). J. Pediat., 20. 604. Milburn, C. L. (1952). Ibid.. 41, 133.

Parry, E. W. (1951). Archives of Disease in Childhood, 26, 358.

Sandblom, P. (1948). Acta paediat., Uppsala, 35. 160. 